Article

\title{
Induction of Hairy Roots on Somatic Embryos of Rhizoclones from Typha domingensis Seedlings
}

\author{
Guadalupe Hernández-Piedra ${ }^{1, *}$, Violeta Ruiz-Carrera ${ }^{2, *}$, Alberto J. Sánchez ${ }^{2}$,
} Alfonso Azpeitia-Morales ${ }^{3}$ and Graciano Calva-Calva ${ }^{4}$ (I)

1 Programa de Doctorado en Ecología y Manejo de Sistemas Tropicales, Universidad Juárez Autónoma de Tabasco, Carretera Villahermosa-Cárdenas Km. 0.5 S/N Entronque a Bosques de Saloya, Villahermosa 86150, Tabasco, Mexico

2 Diagnóstico y Manejo de Humedales Tropicales, Universidad Juárez Autónoma de Tabasco, Carretera Villahermosa-Cárdenas Km. 0.5 S/N Entronque a Bosques de Saloya, Villahermosa 86150, Tabasco, Mexico; alberto.sanchez@ujat.mx

3 Campo Experimental Huimanguillo, Instituto Nacional de Investigaciones Forestales, Agrícolas y Pecuarias, Huimanguillo, Km. 1 Carretera Huimanguillo-Cárdenas, Huimanguillo 86400, Tabasco, Mexico; azpeitia.alfonso@inifap.gob.mx

4 Biotecnología y Bioingeniería, Centro de Investigación y de Estudios Avanzados del IPN, Avenida Instituto Politécnico Nacional 2508, Colonia San Pedro Zacatenco, Ciudad de México 07360, Mexico; gcalva@cinvestav.mx

* Correspondence: guadalupe.hernandezp@ujat.mx (G.H.-P.); violeta@ujat.mx (V.R.-C.)

Received: 7 October 2020; Accepted: 24 November 2020; Published: 1 December 2020

check for updates

\begin{abstract}
A protocol for the induction of hairy roots on somatic embryos of rhizoclones from Typha domingensis seedlings grown in hydroponic rhizotron systems was established for the first time. Rhizogenesis was induced through the agrotransformation of somatic embryos in oblong and scutellar states of development using the K599, LBA9402, and A4 strains of Agrobacterium rhizogenes. The transfection to the embryos was performed by cocultivation of rhizoclones on a Murashige and Skoog mineral medium at $50 \%$ strength (MS0.5), in the dark, at $28 \pm 2{ }^{\circ} \mathrm{C}$ for $72 \mathrm{~h}$. In contrast to nontransformed embryos that did not exhibit any root tissue, transformed embryos presented hairy roots that varied in number, length, and density depending on the bacterial strain, and K599 was the most effective strain. After analysis via optical microscopy, the transformed embryos were collected and transferred to fresh culture media supplemented with $400 \mathrm{mg} \mathrm{mL}^{-1}$ cefotaxime and $10 \mathrm{mg} \mathrm{L}^{-1}$ ascorbic acid. The efficiency of transformation and survival of the oblong and scutellar embryos were similar among the three bacterial strains. The results show that agrotransformation of somatic embryos of rhizoclones from $T$. domingensis is a novel and viable strategy for the generation of genetic transformants of Typha that have potential applications in bioremediation technologies.
\end{abstract}

Keywords: agrotransformation; cattail; rhizogenesis; somatic embryos; hairy roots

\section{Introduction}

The treatment of wastewater from water receptor ecosystems by using emergent aquatic macrophytes (EAM) plant species in phytoremediation-based processes is increasing as a result of the plasticity and physiological capacity of such plants to tolerate, accumulate, or remove both organic and inorganic environmental pollutants; moreover, this approach has led investigations of the genetic transformation of these species to improve the phytoremediation processes and the ecological recovery of the affected ecosystems [1-6] Typically, the plant species used for phytoremediation must be highly capable of adapting to the local environmental conditions of the polluted site, and as a consequence, stable genetic transformants from native species of the impacted sites are preferred $[2,6]$. 
Thus, to enhance the phytoremediation capability of Typha domingensis [7-15], and specifically its eutrophic water receptors $[8,9,16]$, the aim of this work was to investigate the efficiency of the agrotransformation and survival of embryos in the oblong and scutellar stage (Figure 1) induced from in vitro rhizoclones grown in hydroponic rhizotron systems of an ecotype of $T$. domingensis Pers. (cattail). Although the genetic transformation of several EAM species has been achieved in both monocotyledonous and dicotyledonous species by using the bacterial genus Agrobacterium [3,6], which was later renamed as Rhizobium based on comparative 16S rDNA analyses [17], it is well known that, with exception of T. latifolia reported by Nandakumar et al. [18,19], the genetic transformation of the genus Typha remains a challenge because its capacity for transfection includes a narrow range of genotypes, and the utility of the technique is limited by the recalcitrance of many genotypes to regenerate transformed individuals $[5,20,21]$. In this work, the use of germinal lines or somatic embryogenesis systems to facilitate the transformations and to guarantee the regeneration of other monocotyledon species $[22,23]$ were hypothesized to alleviate this problem. For example, the embryogenic callus of Spartina alterniflora were transformed with the A. tumefaciens LBA4404 strain to transport the organomercurial lyase, and mercuric reductase genes have led to the generation of stable genetic lines capable of resisting up to $500 \mu \mathrm{M} \mathrm{HgCl}_{2}$ [23]. Moreover, Mankin et al. [24] proposed the disarmed A. rhizogenes strain $\mathrm{K} 599$ as a candidate to induce stable transformed roots of Arabidopsis thaliana, Zea mays, Lycopersicon esculentum, and Glycine max, and the transformation of Scirpus americanus roots with the A. rhizogenes A4 strain produces clones capable of removing 3.8 and 1.2 times more $\mathrm{Pb}$ and $\mathrm{Cr}$ than those of nontransformed roots $[25,26]$. Nevertheless, regarding the genetic transformation of the Typha genus used in this work, we found only two reports in the literature [18,19], with both from Nandakumar et al., who reported the agrotransformation of $T$. latifolia callus tissue by cocultivation with A. tumefaciens EHA105 and LBA4404 strains. On the other hand, although we were unable to find reports about the genetic transformation of $T$. domingensis, it was chosen because it is a monocotyledonous EAM intercontinentally dispersed in the wetlands of Europe, Asia, and America continent $[27,28]$. In addition, it is a highly flood- and salt-tolerant species $[9,16,29]$ that can grow in eutrophic water with anaerobic substrates $[7,8]$ and can uptake heavy metals $[9,15]$. Furthermore, this species has been used in the floating treatment of wetlands for the phytoremediation of heavy metals from wastewater [10-14], oil-contaminated water [30], and water from wetlands containing high phosphate concentrations [7,31]. Additionally, in Mexico, T. domingensis is known as a cosmopolitan species that can be found in tropical wetlands $[8,32]$ and has expanded its domain into eutrophic areas [16]. In a previous work, we reported that a callus tissue embryogenic line (YC1, yellow callus obtained with $0.5 \mathrm{mg} \mathrm{L}^{-1} 2,4-\mathrm{D}$ ) of $T$. domingensis was able to induce high proliferation of somatic embryos (SEs) in the oblong (SEo) and scutellar (SEsc) states of development [33]. In the present work, genetic transformation for the induction of hairy roots on SE of rhizoclones from T. domingensis seedlings by cocultivation with $A$. rhizogenes was investigated. The efficiency of three wild strains of A. rhizogenes was evaluated for the induction of hairy roots on SEs. The number, length, and density of the hairy roots were monitored on SEs infected with the A. rhizogenes K599, LBA9402, and A4 strains. The results offer, for the first time, a feasible protocol for transforming $T$. domingensis that will strengthen the physiological capacity of its root system with the goal of regenerating transgenic plants from transformed embryos opening the possibilities of further investigations of this plant in phytoremediation technologies for treatment of eutrophic water and soils. 

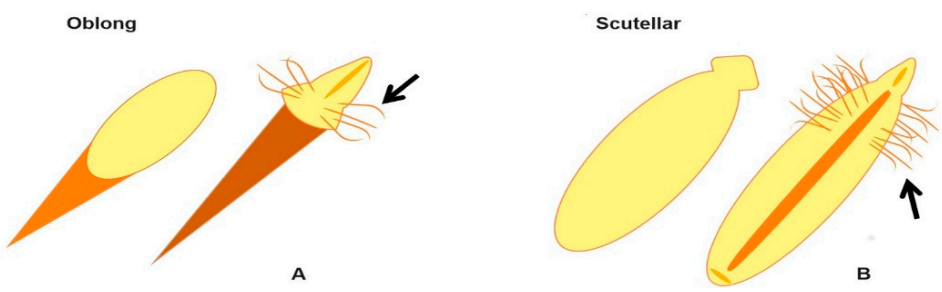

Figure 1. Schematic surface morphology of somatic embryos of T. domingensis in the oblong (A) and scutellar (B) stages, and nontransformed (left) and agrotransformed (right) stages. Both arrows shown the induction of hairy roots. For a complete histogenic model of the somatic embryos of T. domingensis, please refer to Hernández Piedra et al. [33].

\section{Results}

Hairy roots on the surface of SEs of T. domingensis were successfully induced via agrotransformation of in vitro rhizoclones grown in hydroponic rhizotron systems (Figure 2). Based on the natural environmental and nutritional conditions of the sites where wild T. domingensis grows [34], three treatments for the selection of a culture medium that can to support the rhizotron system (Figure 2) were implemented to establish adequate rhizoclone development via the in vitro germination of seeds. These treatments included growth on MS0.1 semisolid culture medium (Figure 2A), growth in liquid MS0.1 medium without growth regulators (Figure 2B), or growth in purified sterile water alone (Figure 2C); in addition, all the treatments included ascorbic acid. Both liquid systems produced friable tissue (Figure 2B,C) with crumbly rhizoclones suitable for the induction of embryogenic callus with embryos in several developmental stages (Figure 2D), as previously reported [33]. Moreover, further experiments revealed that the rhizoclones induced in rhizotron systems, incubated in the dark, yielded a large amount of unpigmented embryos in the scutellar and oblong morphological stages of development (Figure 2D-F), which were suitable for studying the induction of hairy roots by cocultivation with $A$. rhizogenes (Figure $2 \mathrm{H}$ ).

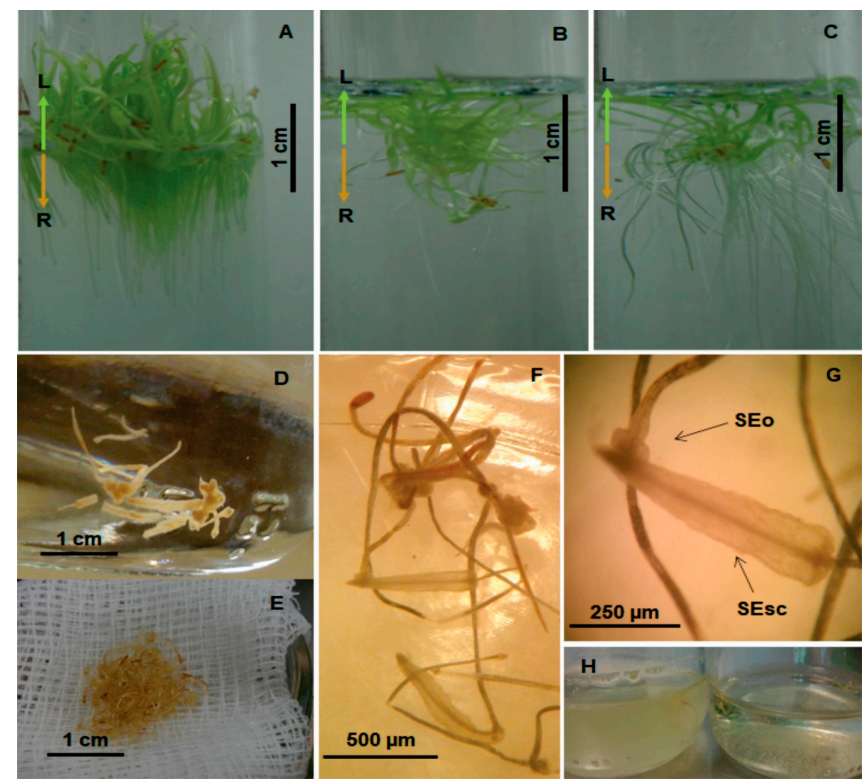

Figure 2. Induction of somatic embryos on rhizoclones from T. domingensis seedlings. Induction started with the in vitro germination of T. domingensis seeds in rhizotron systems with MS0.1 semisolid (A) or liquid (B) culture medium or with sterile purified water alone (C) for the establishment of rhizoclones for the induction of somatic embryos (D), harvested from single cultures (E). Those embryos showing scutellar (SEsc) and oblong (SEo) morphological stages (F,G) were transferred into a suspension of A. rhizogenes $(\mathbf{H})$ for genetic transformation by agrotransfection. The arrows show the magnification of each somatic embryo in $\mathrm{G}$ imagen. $\mathrm{L}=$ Leaf, $\mathrm{R}=$ Roots. 
Three wild A. rhizogenes strains were tested for hairy roots induction on the SEs of rhizoclones from $T$. domingensis seedlings through genetic transformation of a SE line (YC1) in the oblong and scutellar states of development; these strains included the K599, LBA9402, and A4 strains (Figure 3). The transformed embryos clearly showed the presence of hairy roots (Figure 3A-E) emerging from single cells (Figure 3B), whereas the nontransformed embryos did not show root tissue (Figure 3F). Hence, transfection to the embryos by coculture in MS0.5 medium in the dark with any of the three bacteria was successful, although the number, density, and length of the hairy roots were significantly different between the bacterial strains (Table 1). The transformed embryos showing the presence of hairy roots were collected and transferred to a fresh culture medium with $400 \mathrm{mg} \mathrm{mL}^{-1}$ cefotaxime and $10 \mathrm{mg} \mathrm{L}^{-1}$ ascorbic acid, a compound that is indispensable for the survival and health of embryos.

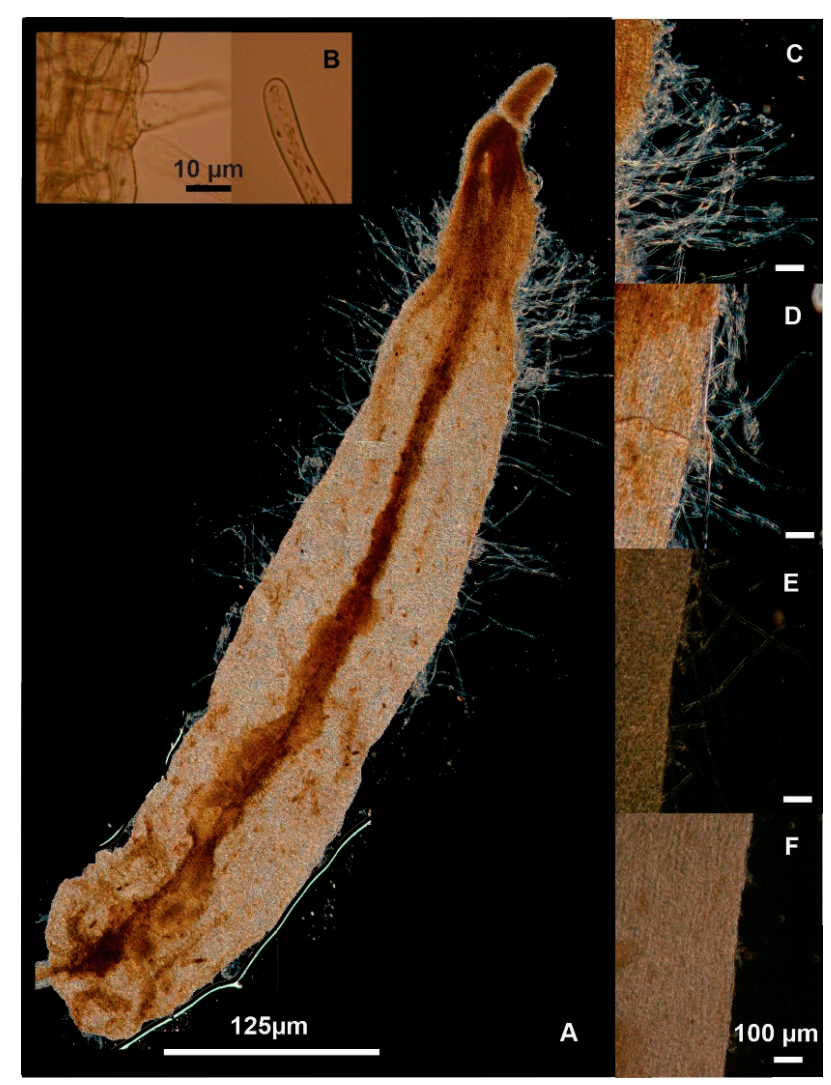

Figure 3. Agrotransformed somatic embryos of T. domingensis after 28 days of coculture with $A$. rhizogenes K599 (A), epidermal tissue with hairy root and a hairy root tip emerging from the infected embryo (B), hairy roots density on the surface of somatic embryos infected with A. rhizogenes K599 (C), and A4 (D) and LBA9402 (E) compared with a non-infected control embryo (F).

The infectivity of $A$. rhizogenes was evaluated by examining the typical appearance and morphology of the hairy roots that emerged on the treated embryos compared with the nontransformed tissue (Figure 4) as suggested in numerous reports $[2,4,5]$. As observed, the formation of the hairy roots on the embryos was due to transfection by using any of the three Agrobacterium strains, but hairy roots were not visible on the noninfected embryos. Additionally, the structure and morphology of the transformed hairy roots were similar and independent of the bacterial strain used (Figures 3 and 4). In general, the hairy structures originated from single epidermal cells (Figure 3B) that looked like tubular unicellular extensions in which the cells contained peripheral cytoplasm and a large central vacuole as reported for classical transformed hairy root tissue [5]. No similar root tissue was observed on the treatment with control embryos (Figure 4A,B). It should be noted that greater abundance of 
hairy roots was observed in the apical and middle areas of the embryos (Figure 4C,D), which are areas reported to have higher abundance of meristematic cells [4,5].

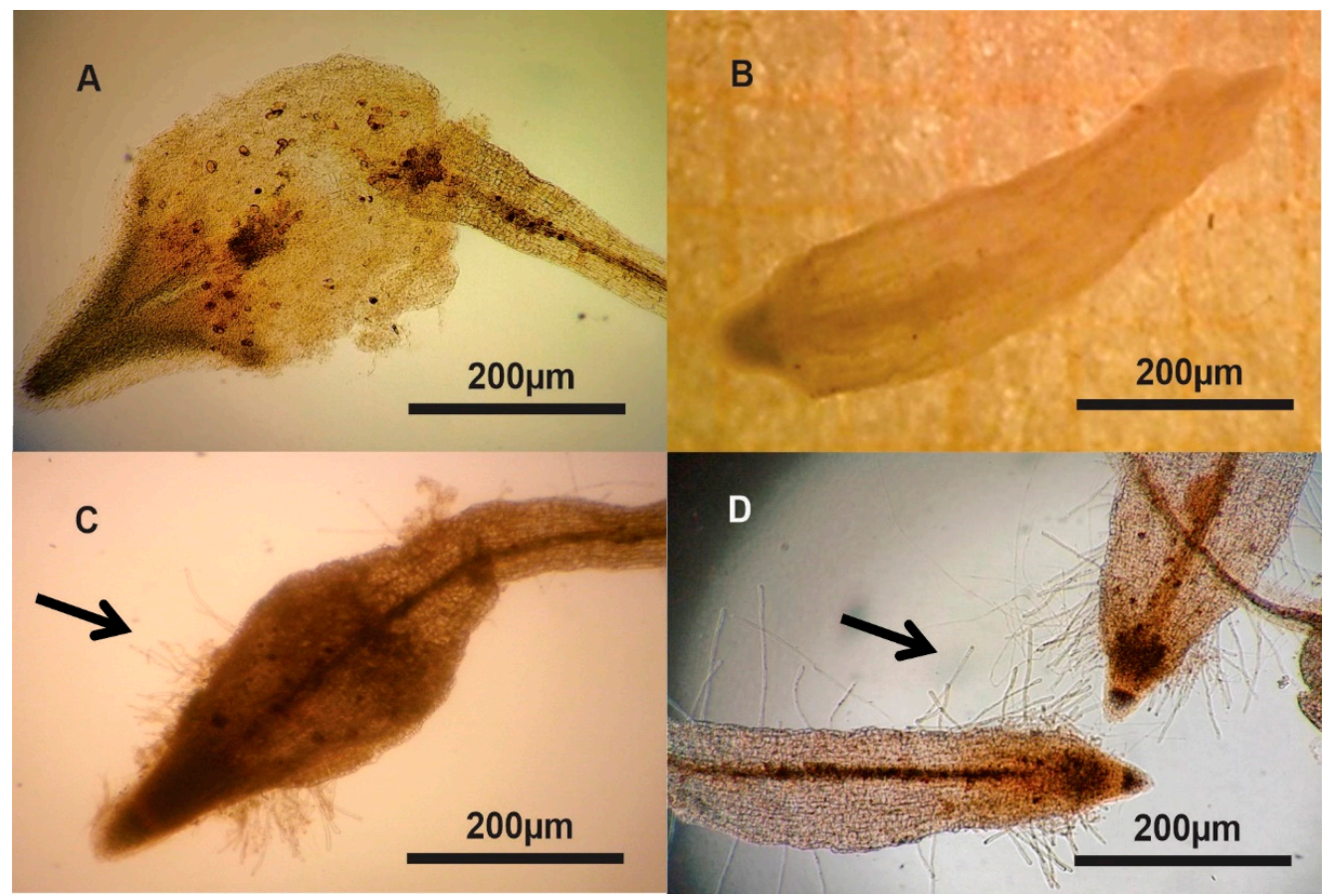

Figure 4. Surface of nontransformed $(\mathbf{A}, \mathbf{B})$ and agrotransformed somatic embryos in the oblong $(\mathbf{A}, \mathbf{C})$ and scutellar (B,D) stages established from the embryogenic rhizoclone after 28 days of transfection with the K599 A. rhizogenes strain. Note the higher abundance of hairy roots (arrows) on the apical tips of the agrotransformed tissue (C,D) compared with the absence of adventitious roots on the nontransformed tissue (A,B).

Table 1. Effects of the Agrobacterium rhizogenes strain on the transformation, survival, and hairy density of Typha domingensis somatic embryos.

\begin{tabular}{|c|c|c|c|c|c|c|}
\hline \multirow[b]{2}{*}{$\begin{array}{l}\text { Somatic } \\
\text { Embryo }\end{array}$} & \multirow[b]{2}{*}{$\begin{array}{l}\text { Dependent } \\
\text { Variable }\end{array}$} & \multicolumn{3}{|c|}{ Strain of Agrobacterium rhizogenes } & \multicolumn{2}{|c|}{ Kruskal-Wallis } \\
\hline & & K599 & LBA9402 & A4 & $\mathbf{H}$ & $\mathbf{P}$ \\
\hline \multirow{2}{*}{$\begin{array}{l}\text { Oblong } \\
\text { (SEo) }\end{array}$} & $\begin{array}{c}\text { Frequency of } \\
\text { transformation (\%) }\end{array}$ & $25 \pm 12$ & $20 \pm 13$ & $14 \pm 16$ & 0.3 & 0.86 \\
\hline & Survival (\%) & $92 \pm 12$ & $71 \pm 12$ & $54 \pm 12$ & 4.7 & 0.09 \\
\hline \multirow{2}{*}{$\begin{array}{l}\text { Scutellar } \\
\text { (SEsc) }\end{array}$} & $\begin{array}{c}\text { Frequency of } \\
\text { transformation (\%) }\end{array}$ & $88 \pm 8$ & $82 \pm 9$ & $79 \pm 10$ & 0.6 & 0.73 \\
\hline & Survival $(\%)$ & $93 \pm 8^{a}$ & $65 \pm 9^{b}$ & $52 \pm 8^{b}$ & 10.9 & 0.003 \\
\hline Total SE & $\begin{array}{c}\text { Frequency of } \\
\text { transformation }(\%)\end{array}$ & $68 \pm 8$ & $59 \pm 9$ & $57 \pm 11$ & 0.8 & 0.68 \\
\hline \multirow[t]{4}{*}{$(\mathrm{SEo}+\mathrm{SEsc})$} & Survival (\%) & $93 \pm 7^{a}$ & $68 \pm 7^{b}$ & $53 \pm 7^{b}$ & 15.7 & 0.002 \\
\hline & Hairy Number (No) & $39.0 \pm 1.2^{\mathrm{a}}$ & $9.0 \pm 7.5^{b c}$ & $22.3 \pm 9.7^{a b}$ & & 0.01 \\
\hline & Length $(\mu \mathrm{m})$ & $363.3 \pm 39.6$ & $165.2 \pm 82.7$ & $306.0 \pm 34.2$ & 3.6 & 0.30 \\
\hline & Density (No/mm) & $21.51 \pm 3.3^{\mathrm{a}}$ & $5.64 \pm 4.7^{\mathrm{b}}$ & $13.04 \pm 5.6^{\mathrm{ab}}$ & & 0.02 \\
\hline
\end{tabular}

The data represent the means \pm standard error of the treated embryos. Different letters in columns denote a group of means that are significantly different $(p<0.05)$. $\mathrm{H}=$ test statistic for the Kruskal-Wallis $\mathrm{H}$ test; $\mathrm{P}, p$-value for the Kruskal-Wallis test or from the F = Fisher LSD test.

The effects of the A. rhizogenes strain, and the morphological stage of the SE, on the agrotransformation process were evaluated and the results revealed that both factors affected the transformation frequency, survival, and hairy density (Table 1). Evidently, the efficiency of 
transformation for both the oblong and the scutellar embryos was similar for each of the three bacterial strains; however, survival was affected by the Agrobacterium strain but not the morphological stage. Interestingly, the SEs infected with the K599 strain produced a greater number, length, and density of hairy structures than those infected with the LBA9402 and A4 strains, and these results are consistent those discussed above for Figure 3C. However, in general, the Agrobacterium strains did not affect the effectiveness of the agrotransformation process of either the SEo or SEsc embryos (Kruskall-Wallis test; $p>0.05$ ). It should be noted that the SEo stage showed lower frequencies of transformation than the SEsc stage, which affected the total number of SEs transformed (SEo plus SEsc). This finding is consistent with the observation that the efficiency of transformation was highly variable between the morphological stage of embryos (25-88\%). Notably, frequent contamination was observed during cocultivation with the A4 and LB9402 strains (Figure $2 \mathrm{H}$, left flask), which may have resulted in the significantly different and lower level of survival of the SEo stage of each bacterial strain (92-54\%) as confirmed by the Kruskall-Wallis test $(p=0.09)$, and the significantly different results for the SEsc stage (Kruskall-Wallis test; $p=0.003$ ). Notably, the K599 strain stood out in all embryos regarding the frequency and survival of the transformed embryos, as well as the number of hairy roots (Table 1). Finally, the frequency of transformation in total SEs was substantially greater for the K599 strain. Moreover, the survival of the SEsc and the total SEs was significantly greater (Kruskall-Wallis test; $p=0.002)$ with the K599 strain.

\section{Discussion}

The SEs of T. domingensis developed typical hairy roots through the transfection of rhizoclones with the A. rhizogenes K599, LBA9402, and A4 strains. The phenotype of these hairy roots was similar to the phenotype of hairy roots reported in the transgenic embryos of Bouteloua gracilis [35]. The virulence was different for each of the three A. rhizogenes strains; however, the K599 strain stood out in terms of its hypervirulence, and the A4 strain stood out in terms of its virulence. Hypervirulent strains of Agrobacterium spp., have been proven effective in other species, such as Cyclamen persicum, in which embryogenic callus cocultivated with the A. tumefaciens EHA105 hypervirulent strain resulted in a transformation efficiency twice as high as that achieved with the A. tumefaciens LBA4404 virulent strain [36]; moreover, similar results were achieved with the A. rhizogenes K599 and LBA9402 strains in this study. The K599 strain, which is equivalent to the NCPPB2659 cucumopine biovar, harbors the pRi2659 plasmid (ADN-T) that transports the aux1 and aux2 genes for auxin autotrophic cell division and biosynthesis and the onset of hairy roots, including root loci oncogenic genes (mainly $\operatorname{rol} A, B$, and $C$ genes), and other genes with unidentified function, such as open reading frames $[24,37,38]$. The genes cluster $a u x$ and $\operatorname{rol} A, B$, and $C$ play a part in the infection and induction of hairy roots [39].

The root hairs in the SEs of T. domingensis in both the oblong and scutellar embryogenic states developed on the epidermis towards the apex and middle of the cotyledon area. Similarly, the root hairs on the root of $A$. thaliana emerge from epidermal cells and form short hairs on the basal area oriented towards the root apex [40], thus showing acropetal development of root hairs, which is characteristic of axonomorphic roots [41].

The critical requirements to confirm the genetic agrotransformation of a plant tissue include the identification of transformed cells or target tissue, evidence of the presence and/or expression of the transferred T-DNA in the nuclear genome, and the regeneration of transgenic plants [42,43]. In this work, the first requirement was confirmed by the selection of embryos showing hairy roots with the typical morphological pattern of such tissue, such as branching and growth on the medium without plant hormones. The biological effect and confirmation for the genetic transformation by the presence of the transferred DNA (T-DNA) of A. rhizogenes to the target plant tissue is still under study, as there are certain limitations in the case of recalcitrant species $[39,44]$. The infectivity of the strains has been confirmed via morphologic markers of the hairy phenotype in the Agrobacterium-treated SEs [35] as well as by the coculture technique performed in this study. Similar to the study that induced transgenic embryos of Bouteloua gracilis, polymerase chain reaction (PCR), Southern blot, and Northern 
blot analyses are commonly used to confirm the presence of the rol A genes in hairy SEs; however, these molecular techniques are not infallible for confirming genetic transformation. For example, the secondary embryos of Coffea canephora transfected with the A4 rhizogenic wild strain molecularly revealed a stable transformation, but without the hairy phenotype [45]. In contrast, the presence of the hairy root morphological phenotype in agrotransformed tissue with $A$. rhizogenes wild strains provides proof for the success of the genetic agrotransformation [20,24,35,37,44-46].

Knowledge of the interaction between Agrobacterium and the structure and composition of the outer cell wall of the protodermic cells that cover SEs is limited [47]. The transfective susceptibility of A. tumefaciens in root hairs may be explained by the biochemical changes that take place on the cell surface [48]. The biochemical mechanism was revealed by the presence of polar binding polysaccharides and an unknown receptor molecule based on the greater number of adhered bacteria. As previously reported [48], the adherence of Agrobacterium to the surface of embryos might have been improved by the acid $\mathrm{pH}$ (5.5) of the culture medium used in the coculture, the absence of accessory structures such as cutin in this type of tissue [47], or the addition of ascorbic acid to the culture system [49]. In addition, Agrobacterium has been reported to show enhanced virulence in the presence of phenolic compounds [50], such as those produced by T. domingensis embryos [33]. Thus, consistent with these results, the acid $\mathrm{pH}$, addition of ascorbic acid, and liquid state of the coculture medium all favored biochemical adherence of the bacteria to the embryo surface, thereby enhancing the agrotransformation process.

The high variability in the frequency of transformation and survival of the transformed tissue observed in this work agree with studies of transformations mediated by Agrobacterium of the monocotyledon species, such as Triticum aestivum (wheat), Oryza sativa (rice), and Zea mays (maize), for which high variable frequencies of transformation have been reported [51,52]. Additionally, a general variability for the efficiency of the agrotransformation of immature $(14.9 \%)$ or mature $(9.8 \%)$ embryos of wheat, and low efficiencies of transformation of zygotic embryos of maize (1.21-10.96\%) with the A. rhizogenes K599 strain, with or without extra copies of virulence genes, have been reported [25]. Furthermore, high variability in the transformation efficiency has also been reported by using the electroporation technique for some rice species, and it produced more than $80 \%$ efficiency for some varieties but less than $2 \%$ for others [53].

Overall, since hairy roots can emerge only from single transformed cells expressing of transferred T-DNA $[42,43,54]$, the present results suggest that the hairy root specific phenotype may become a practical morphologic feature for the early identification of an agrotransformation event in embryos because it might not require additional molecular or biochemical techniques. In addition, this approach provides a simple and rapid method for the genetic transformation of Typha species through the coculture of embryos with Agrobacterium, although molecular techniques should be used to validate the relationship between the hairy phenotype and the genetic transformation success. Such strategy can be combined with the current machine learning algorithms technology, which have emerged as promising tools for prediction of hairy root cultures, among other in vitro cultures types [55,56], along with the optimization of environmental conditions to achieve maximum productivity and efficiency of hairy root cultures of Typha domingensis as a valuable plant for biotechnological applications. On the other hand, it is still uncertain why the presence of ascorbic acid enhanced the survivance and health of embryos as previously reported [36]; however, this compound has been used in genetic transformation events of several plant species due to its antioxidant properties [57,58] Additionally, the frequency of infection with the $A$. rhizogenes strains used in this work should be studied for the transformation of other dicotyledonous species. Moreover, although the regeneration of transformed plants is still a pending issue in this work, whether the agrotransformation of other plant species by using the present approach results was successful, this could be a good advance in the area of plant biotechnology.

In conclusion, infection of $T$. domingensis somatic embryos, in the oblong and scutellar stage of development, with the three $A$. rhizogenes strains was an efficient strategy for inducing hairy roots, and the K599 strain was the most effective. The results provide new insights in the area of plant 
biotechnology by providing a new protocol for genetic transformation of plant species recalcitrant to genetic transformations. Additional studies are necessary to molecularly confirm the transgenic nature of the tissues and the regeneration of transformed plants potentially useful for biotechnological applications for the removal of pollutants from hypereutrophic wastewater and the production of natural compounds.

\section{Materials and Methods}

\subsection{Germination of Typha Seeds and Establishment of Rhizoclones on Somatic Embryos (SEs)}

Seeds were isolated from the achenes of $T$. domingensis and germinated in rhizotron systems to establish rhizoclones. The achenes were collected from the tropical wetlands of Villahermosa, Tabasco $\left(17^{\circ} 59^{\prime} 9.91^{\prime \prime} \mathrm{N}\right.$ and $\left.17^{\circ} 57^{\prime} 48.98^{\prime \prime} \mathrm{E}\right)$, Mexico, and deposited in the dry plant collection of the Herbarium in the Universidad Juárez Autónoma de Tabasco (UJAT-Herbarium 35227). The seeds used for this work were stored in a desiccator at room temperature, and 5-15 seeds were sowed in each rhizotron unit (sRU) established in test tubes with $20 \mathrm{~mL}$ of Murashige and Skoog basal medium [59] at one-tenth ionic strength (MS0.1), in either semisolid (agar 4\% w/v) or liquid format with $\mathrm{pH} 6.5$ and formulated with MS vitamins, without growth regulators in an autotrophic regime. Additionally, a sRU with deionized sterile water was prepared as a control. The rhizotron systems in the semisolid medium were covered with a water film of $1 \mathrm{~cm}$. After 15 days germination, the root system of seedlings with $1 \mathrm{~cm}$ length and with similar development (pair of leaves, radicle with adventitious root) were separated from the caulinar base and transferred into a new sRU for the establishment of rhizoclones (Figure 2). Individual roots were positioned vertically on the surface of the semisolid culture medium, avoiding injuries, and were incubated under photoperiod (16/8 h light/darkness) by using cold white light (Philips, USA), at a photon flux density of $20 \mu \mathrm{mol}$ photons $\mathrm{m}^{-2} \mathrm{~s}^{-1}$ (Quantum Light Meter; Spectrum Technologies, Aurora, IL, USA), and a temperature of $28 \pm 2{ }^{\circ} \mathrm{C}$. The rhizoclones were used for the induction of SEs by incubation in the dark in MS culture medium at half ionic strength (MS0.5), and supplemented with vitamins, sucrose ( $3 \%$ w/v), ascorbic acid $\left(10 \mathrm{mg} \mathrm{L}^{-1}\right)$, and $0.5 \mathrm{mg} \mathrm{L}^{-1} 2,4-\mathrm{D}$, as described previously [33]. The SEs in the oblong (SEo) and scutellar (SEsc) stages of development were isolated from the embryogenic line $\mathrm{YC} 1$ of $\mathrm{T}$. domingensis that was established and maintained as described above.

\subsection{Agrobacterium Rhizogenes Strains}

The A. rhizogenes K599 (cucumopine-type), LBA9402 (agropine-type), and A4 (agropine-type) strains were provided by the Metabolic Engineering group at CINVESTAV-IPN. The bacterial strains were kept at $4{ }^{\circ} \mathrm{C}$ in Luria-Bertoni semisolid culture medium (LB) at $\mathrm{pH}$ 7. The bacteria were first activated by transferal to the LB liquid culture medium using commercial yeast extract and incubation in an orbital shaker at $30^{\circ} \mathrm{C}$ and $130 \mathrm{rpm}$ for $48 \mathrm{~h}$. The concentration of bacteria for infection of the embryogenic tissue was adjusted at $\mathrm{DO}_{600} 0.8-1$ to proceed to inoculation as described by Jimenez-Antaño et al. [60].

\subsection{Induction of Transformed Hairy Roots on SE of Typha Domingensis}

The inoculation of the SE of $T$. domingensis with the A. rhizogenes strains was performed by coculture. A bacterial suspension with $48 \mathrm{~h}$ of growth was mixed at a ratio of 1:5 (final volume $30 \mathrm{~mL}$ ) with the T. domingensis embryo MS0.5 medium culture as described for embryogenic induction, although the medium was not supplemented with phytoregulators. The mixture was incubated in the dark, at $28 \pm 2{ }^{\circ} \mathrm{C}$, for $72 \mathrm{~h}$, and it was stirred constantly (130 rpm, $\left.60 \mathrm{~min}\right)(n=4)$. The embryogenic callus and the SEo and SEsc in the embryogenic mixture of each culture unit were filtered through a sterile gauze, transferred to $30 \mathrm{~mL}$ of MS0.5 medium with $400 \mathrm{mg} / \mathrm{L}$ cefotaxime $(n=4)$ to eliminate the residual A. rhizogenes, and kept under the previous environmental conditions for 28 days. 


\subsection{Experimental Model}

The effect of the A. rhizogenes K599, LBA9402, and A4 strains on the efficiency of transformation of T. domingensis EL-YC1 was studied. The observational unit was the viable SEs $(n=40$ per treatment), which were randomly sampled from the MS medium with cefotaxime. The transformed embryos were separated following a previously reported protocol [33]. The survival, hairy morphology, and transformation frequency of all viable SEs, SEos, and SEscs were analyzed at the end of the experiment.

\subsection{Agrotransformation Quantification}

Survival was estimated considering the excessive growth of bacteria [51] since the number of viable embryos per treatment decreased with the three strains. The visual indicators used to calculate the frequency of agrotransformation were the hairy SEo and SEsc phenotypes observed under a stereomicroscope (Carl Zeizz ${ }^{\circledR}$, Göttingen, Germany). The magnitude of hairiness in the SEo and SEsc stages was quantified through an image analysis $(n=3)$ of the number (No.), length $(\mu \mathrm{m})$, and density (No. $\mu \mathrm{m}$ ) of the hairy units [60]. The SE images were digitized using an Axio Scope A1 optical microscope (Carl Zeizz ${ }^{\circledR}$ ) equipped with an AxioCam ERc5s camera (Carl Zeizz ${ }^{\circledR}$ ). The fields of view of interest were selected using the $10 \times, 40 \times$, and $100 \times+1.25 \times$ objective lens in the optovar $\left(\right.$ Carl Zeizz $\left.^{\circledR}\right)$ and the SEN/2011 program (Carl Zeizz ${ }^{\circledR}$ Microscopy GmbH, 2011).

\subsection{Statistical Analyses}

Kolmogorov-Smirnov and Cochran $C$ tests were used to verify the assumptions of normality and homoscedasticity of the data. The Fisher's least significant difference test (LSD) or the Kruskal-Wallis $\mathrm{H}$ test were used to estimate the statistical difference between treatments by using a significance level of 0.05. Statistica V8 (Stat Soft Inc., Tulsa, OK, USA) software was used for statistical analyses.

Author Contributions: Conceptualization, G.H.-P., V.R.-C.; methodology, G.H.-P., V.R.-C., G.C.-C.; validation, V.R.-C.; investigation, G.H.-P., V.R.-C.; resources, V.R.-C., G.C.C.; data curation, G.H.-P., V.R.-C., A.J.S.; writing-original draft preparation, G.H.-P., V.R.-C., A.J.S., G.C.-C.; writing-review and editing, G.H.-P., V.R.-C., A.J.S., G.C.-C., A.A.-M.; supervision, V.R.C. All authors have read and agreed to the published version of the manuscript.

Funding: This research was partially financed by PRODEP-SEP-MEXICO UJAT-CA-177 and the Thematic Network CONACYT-RECORECOS 88990-B.

Acknowledgments: The first author thanks CONACyT for the support given through the Scholarship for Doctoral Studies.

Conflicts of Interest: The authors declare no conflict of interest. The funders had no role in the design of the study; in the collection, analyses, or interpretation of data; in the writing of the manuscript, or in the decision to publish the results.

\section{References}

1. Doran, P.M. Application of plant tissue cultures in phytoremediation research: Incentives and limitations. Biotechnol. Bioeng. 2009, 103, 60-76. [CrossRef]

2. Agostini, E.; Talano, M.A.; González, P.S.; Oller, A.L.W.; Medina, M.I. Application of hairy roots for phytoremediation: What makes them an interesting tool for this purpose? Appl. Microbiol. Biotechnol. 2013, 97, 1017-1030. [CrossRef] [PubMed]

3. Ibañez, S.; Talano, M.; Ontañon, O.; Suman, J.; Medina, M.I.; Macek, T.; Agostini, E. Transgenic plants and hairy roots: Exploiting the potential of plant species to remediate contaminants. New Biotechnol. 2016, 33, 625-635. [CrossRef] [PubMed]

4. Habibi, P.; De Sa, M.F.G.; Makhzoum, A.; Malik, S.; Da Silva, A.L.L.; Hefferon, K.; Soccol, C.R. Bioengineering Hairy Roots: Phytoremediation, secondary metabolism, molecular pharming, plant-plant interactions and biofuels. In Sustainable Agriculture Reviews; Lichtfouse, E., Ed.; Springer: Cham, Switzerland, 2017; pp. 213-251. 
5. Srivastava, V.; Mehrotra, S.; Mishra, S. Hairy Roots: An Effective Tool of Plant Biotechnology; Springer Nature: Berlin/Heidelberg, Germany, 2018.

6. Iqbal, M.C.M.; Iqbal, S.S. Remediation of potentially toxic elements through transgenic plants: In Vitro Studies and the Way Forward. In Transgenic Plant Technology for Remediation of Toxic Metals and Metalloids; Academic Press: Cambridge, MA, USA, 2019; pp. 103-128.

7. Li, S.; Lissner, J.; Mendelssohn, I.A.; Brix, H.; Lorenzen, B.; McKee, K.L.; Miao, S. Nutrient and growth responses of cattail (Typha domingensis) to redox intensity and phosphate availability. Ann. Bot. 2010, 105, 175-184. [CrossRef] [PubMed]

8. Dhir, B. Aquatic plant species and removal of contaminants. In Phytoremediation: Role of Aquatic Plants in Environmental Clean-Up; Springer: New Delhi, India, 2013; pp. 21-50.

9. Dhir, B. Role of Wetlands. In Phytoremediation: Role of Aquatic Plants in Environmental Clean-Up; Springer: New Delhi, India, 2013; pp. 65-93.

10. Hegazy, A.K.; Abdel-Ghani, N.T.; El-Chaghaby, G.A. Phytoremediation of industrial wastewater potentiality by Typha domingensis. Int. J. Environ. Sci. Technol. 2011, 8, 639-648. [CrossRef]

11. Mojiri, A.; Aziz, H.A.; Zahed, M.; Aziz, S.Q.; Selamat, M.R.B. Phytoremediation of Heavy Metals from Urban Waste Leachate by Southern Cattail (Typha domingensis). Int. J. Sci. Res. Environ. Sci. 2013, 1, 63-70. [CrossRef]

12. Vera, A.; Ramos, K.; Camargo, E.; Andrade, C.; Núñez, M.; Delgado, J.; Morales, E. Phytoremediation of wastewater with high lead content and using Typha domingensis and Canna generalis. Rev. Técnica Fac. Ing. Univ. Zulia 2016, 39, 88-95.

13. Shehzadi, M.; Fatima, K.; Imran, A.; Mirza, M.S.; Khan, Q.M.; Afzal, M. Ecology of bacterial endophytes associated with wetland plants growing in textile effluent for pollutant-degradation and plant growth-promotion potentials. Plant Biosyst. Int. J. Deal. All Asp. Plant Biol. 2016, 150, 1261-1270. [CrossRef]

14. Usman, K.; Al-Ghouti, M.A.; Abu-Dieyeh, M.H. Phytoremediation: Halophytes as Promising Heavy Metal Hyperaccumulators. In Heavy Metals; Saleh, H.M., Aglan, R.F., Eds.; IntechOpen: London, UK, 2018.

15. Oliveira, J.P.V.; Pereira, M.P.; Duarte, V.P.; Corrêa, F.; Castro, E.M.; Pereira, F.J. Cadmium tolerance of Typha domingensis Pers. (Typhaceae) as related to growth and leaf morphophysiology. Braz. J. Biol. 2017, 78, 509-516. [CrossRef]

16. Olguín, E.J.; Sánchez-Galván, G. Aquatic phytoremediation: Novel insights in tropical and subtropical regions. Pure Appl. Chem. 2010, 82, 27-38. [CrossRef]

17. Young, J.M.; Kuykendall, L.D.; Martinez-Romero, E.; Kerr, A.; Sawada, H. A revision of Rhizobium Frank 1889, with an emended description of the genus, and the inclusion of all species of Agrobacterium Conn 1942 and Allorhizobium undicola de Lajudie et al. 1998 as new combinations: Rhizobium radiobacter, R. rhizogenes, R. rubi, R. undicola and R. vitis. Int. J. Syst. Evol. Microbiol. 2001, 51, 89-103.

18. Nandakumar, R.; Chen, L.; Rogers, S.M. Factors Affecting the Agrobacterium-Mediated Transient Transformation of the Wetland Monocot, Typha latifolia. Plant Cell Tissue Organ Cult. 2004, 79, 31-38. [CrossRef]

19. Nandakumar, R.; Chen, L.; Rogers, S.M.D. Agrobacterium-mediated transformation of the wetland monocot Typha latifolia L. (Broadleaf cattail). Plant Cell Rep. 2004, 23, 744-750. [CrossRef]

20. Georgiev, M.I.; Agostini, E.; Ludwig-Müller, J.; Xu, J. Genetically transformed roots: From plant disease to biotechnological resource. Trends Biotechnol. 2012, 30, 528-537. [CrossRef]

21. Hofmann, N.R. A Breakthrough in Monocot Transformation Methods. Plant Cell 2016, 28, 1989. [CrossRef]

22. Koetle, M.J.; Finnie, J.F.; Balázs, E.; Van Staden, J. A review on factors affecting the Agrobacterium-mediated genetic transformation in ornamental monocotyledonous geophytes. S. Afr. J. Bot. 2015, 98, 37-44. [CrossRef]

23. Czakó, M.; Feng, X.; He, Y.; Liang, D.; Márton, L. Transgenic Spartina alterniflora for phytoremediation. Environ. Geochem. Health 2006, 28, 103-110. [CrossRef]

24. Mankin, S.L.; Hill, D.S.; Olhoft, P.M.; Toren, E.; Wenck, A.R.; Nea, L.; Xing, L.; Brown, J.A.; Fu, H.; Ireland, L.; et al. Disarming and sequencing of Agrobacterium rhizogenes strain K599 (NCPPB2659) plasmid pRi2659. Vitr. Cell. Dev. Biol. Anim. 2007, 43, 521-535. [CrossRef]

25. Alfaro-Saldaña, E.F.; Pérez-Molphe-Balch, E.; Santos-Díaz, M.D.S. Generation of transformed roots of Scirpus americanus Pers. and study of their potential to remove $\mathrm{Pb}^{2+}$ and $\mathrm{Cr}^{3+}$. Plant Cell Tissue Organ Cult. 2016, 127, 15-24. [CrossRef] 
26. Prasad, M.N.V. Prospects for Manipulation of Molecular Mechanisms and Transgenic Approaches in Aquatic Macrophytes for Remediation of Toxic Metals and Metalloids in Wastewaters. In Transgenic Plant Technology for Remediation of Toxic Metals and Metalloids; Prasad, M.N.V., Ed.; Elsevier BV: Amsterdam, The Netherlands, 2019; pp. 395-428.

27. Esteves, B.S.; Enrich-Prast, A.L.E.X.; Suzuki, M.S. Allometric relations for Typha domingensis natural populations. Acta Limnol. Bras. 2008, 20, 305-311.

28. Zhou, B.; Tu, T.; Kong, F.; Wen, J.; Xu, X. Revised phylogeny and historical biogeography of the cosmopolitan aquatic plant genus Typha (Typhaceae). Sci. Rep. 2018, 8, 1-7. [CrossRef] [PubMed]

29. Akhtar, N.; Hameed, M.; Nawaz, F.; Ahmad, K.S.; Hamid, A.; Segovia-Salcedo, C.; Shahnaz, M.M. Leaf anatomical and biochemical adaptations in Typha domingensis Pers. ecotypes for salinity tolerance. Bot. Sci. 2017, 95, 807. [CrossRef]

30. Afzal, M.; Rehman, K.; Shabir, G.; Tahseen, R.; Ijaz, A.; Hashmat, A.J.; Brix, H. Large-scale remediation of oil-contaminated water using floating treatment wetlands. NPJ Clean Water 2019, 2, 3. [CrossRef]

31. Di Luca, G.; Maine, M.; Mufarrege, M.; Hadad, H.R.; Bonetto, C. Influence of Typha domingensis in the removal of high P concentrations from water. Chemosphere 2015, 138, 405-411. [CrossRef] [PubMed]

32. Reddy, A.R.; Rasineni, G.K.; Raghavendra, A.S. The impact of global elevated $\mathrm{CO}_{2}$ concentration on photosynthesis and plant productivity. Curr. Sci. 2010, 99, 46-57.

33. Hernández-Piedra, G.; Ruiz-Carrera, V.; Sánchez, A.J.; Hernández-Franyutti, A.; Azpeitia-Morales, A. Morpho-histological development of the somatic embryos of Typha domingensis. PeerJ 2018, 6, e5952. [CrossRef]

34. Rodríguez-Rodríguez, E. Lagunas Continentales de Tabasco; Colección José, N. Rovirosa Biodiversidad, Desarrollo Sustentable y Trópico Húmedo; Universidad Juárez Autónoma de Tabasco: Villahermosa, Tabasco, Mexico, 2002; 243p.

35. Aguado-Santacruz, G.A.; Rascón-Cruz, Q.; Moreno-Gómez, B.; Guevara-González, R.G.; Guevara-Olvera, L.; Jiménez-Bremont, J.F.; Arévalo-Gallegos, S.; Moya, E.G. Genetic transformation of blue grama grass with the rolA gene from Agrobacterium rhizogenes: Regeneration of transgenic plants involves a "hairy embryo" stage. Vitr. Cell. Dev. Biol. Anim. 2009, 45, 681-692. [CrossRef]

36. Ratjens, S.; Mortensen, S.; Kumpf, A.; Bartsch, M.; Winkelmann, T. Embryogenic Callus as Target for Efficient Transformation of Cyclamen persicum Enabling Gene Function Studies. Front. Plant Sci. 2018, 9,1-39. [CrossRef]

37. Xiang, T. Cucumopine type Agrobacterium rhizogenes K599 (NCPPB2659) T-DNA-mediated plant transformation and its application. Bangladesh J. Bot. 2016, 45, 935-945.

38. Desmet, S.; Dhooghe, E.; De Keyser, E.; Van Huylenbroeck, J.; Müller, R.; Geelen, D.; Lütken, H. Rhizogenic agrobacteria as an innovative tool for plant breeding: Current achievements and limitations. Appl. Microbiol. Biotechnol. 2020, 104, 2435-2451. [CrossRef]

39. Mauro, M.L.; Costantino, P.; Bettini, P.P. The never ending story of rol genes: A century after. Plant Cell Tissue Organ Cult. 2017, 131, 201-212. [CrossRef]

40. Gendre, D.; Baral, A.; Dang, X.; Esnay, N.; Boutté, Y.; Stanislas, T.; Vain, T.; Claverol, S.; Gustavsson, A.; Lin, D.; et al. Rho-of-plant activated root hair formation requires Arabidopsis YIP4a/b gene function. Development 2019, 146, dev168559. [CrossRef] [PubMed]

41. Evert, R.F. Esau's Plant Anatomy: Meristems, Cells, and Tissues of the Plant Body: Their Structure, Function, and Development; John Wiley \& Sons: Hoboken, NJ, USA, 2006.

42. Ziemienowicz, A. Agrobacterium-mediated plant transformation: Factors, applications and recent advances. Biocatal. Agric. Biotechnol. 2014, 3, 95-102. [CrossRef]

43. Rashid, B.; Tariq, M.; Khalid, A.; Shams, F.; Ali, Q.; Ashraf, F.; Ghaffar, I.; Khan, M.I.; Rehman, R.; Husnain, T. Crop Improvement: New Approaches and Modern Techniques. Plant Gene Trait. 2017, 8, 18-30. [CrossRef]

44. Wang, S.; Song, Y.; Xiang, T.; Wu, P.; Zhang, T.; Wu, D.; Zhou, S.; Li, Y. Transgenesis of Agrobacterium rhizogenes K599 orf3 into plant alters plant phenotype to dwarf and branch. Plant Cell Tissue Organ Cult. 2016, 127, 207-215. [CrossRef]

45. Kumar, V.; Satyanarayana, K.V.; Itty, S.S.; Indu, E.P.; Giridhar, P.; Chandrashekar, A.; Ravishankar, G.A. Stable transformation and direct regeneration in Coffea canephora P ex. Fr. by Agrobacterium rhizogenes mediated transformation without hairy-root phenotype. Plant Cell Rep. 2006, 25, 214-222. [CrossRef] 
46. Chandra, S. Natural plant genetic engineer Agrobacterium rhizogenes: Role of T-DNA in plant secondary metabolism. Biotechnol. Lett. 2012, 34, 407-415. [CrossRef]

47. Dobrowolska, I.; Majchrzak, O.; Baldwin, T.C.; Kurczyńska, E.U. Differences in protodermal cell wall structure in zygotic and somatic embryos of Daucus carota (L.) cultured on solid and in liquid media. Protoplasma 2011, 249, 117-129. [CrossRef]

48. Matthysse, A.G. Attachment of Agrobacterium to plant surfaces. Front. Plant Sci. 2014, 5, 252. [CrossRef]

49. Kumar, A.; Simmi, P.S.; Giridhar, P. Cell wall remodelling involving galactomannan de-branching influence Agrobacterium tumefaciens-mediated transformation of Coffea canephora somatic embryos. Plant Cell Tissue Organ Cult. 2018, 134, 369-382. [CrossRef]

50. Nester, E.W. Agrobacterium: Nature's genetic engineer. Front. Plant Sci. 2015, 5, 1-16. [CrossRef]

51. Kumar, R.; Mamrutha, H.M.; Kaur, A.; Venkatesh, K.; Sharma, D.; Singh, G.P. Optimization of Agrobacterium-mediated transformation in spring bread wheat using mature and immature embryos. Mol. Biol. Rep. 2019, 46, 1845-1853. [CrossRef] [PubMed]

52. Mohammed, S.; Samad, A.A.; Rahmat, Z. Agrobacterium-Mediated Transformation of Rice: Constraints and Possible Solutions. Rice Sci. 2019, 26, 133-146. [CrossRef]

53. Cheng, Y.; Zhu, W.; Chen, Y.; Ito, S.; Asami, T.; Wang, X. Brassinosteroids control root epidermal cell fate via direct regulation of a MYB-bHLH-WD40 complex by GSK3-like kinases. eLife 2014, 3, e02525. [CrossRef] [PubMed]

54. Nadeem, M.A.; Nawaz, M.A.; Shahid, M.Q.; Doğan, Y.; Comertpay, G.; Yıldız, M.; Hatipoğlu, R.; Ahmad, F.; Alsaleh, A.; Labhane, N.; et al. DNA molecular markers in plant breeding: Current status and recent advancements in genomic selection and genome editing. Biotechnol. Biotechnol. Equip. 2018, 32, 261-285. [CrossRef]

55. Goswami, M.; Akhtar, S.; Osama, K. Strategies for Monitoring and Modeling the Growth of Hairy Root Cultures: An In Silico Perspective. In Hairy Roots; Srivastava, V., Mehrotra, S., Mishra, S., Eds.; Springer: Singapore, 2018.

56. Hesami, M.; Jones, A.M.P. Application of artificial intelligence models and optimization algorithms in plant cell and tissue culture. Appl. Microbiol. Biotechnol. 2020, 104, 9449-9485. [CrossRef]

57. Semiarti, E. Peranan Vitamin C dan acetosyringone pada transformasi genetik anggrek Vanda tricolor Lindl. var. suavis melalui Agrobacterium tumefaciens. Bionatura 2012, 14, 3.

58. Yong, W.T.L.; Henry, E.S.; Abdullah, J.O. Enhancers of Agrobacterium-mediated Transformation of Tibouchina semidecandra Selected on the Basis of GFP Expression. Trop. Life Sci. Res. 2010, 21, 115-130.

59. Murashige, T.; Skoog, F. A revised medium for rapid growth and bioassay with tobacco tissue culture. Physiol. Plant 1962, 15, 473-497. [CrossRef]

60. An efficient heat-shock protocol for transformation of Agrobacterium rhizogenes without spontaneous generation to antibiotic resistance. Plant Omics 2018, 11, 20-29. [CrossRef]

Publisher's Note: MDPI stays neutral with regard to jurisdictional claims in published maps and institutional affiliations.

(C) 2020 by the authors. Licensee MDPI, Basel, Switzerland. This article is an open access article distributed under the terms and conditions of the Creative Commons Attribution (CC BY) license (http://creativecommons.org/licenses/by/4.0/). 